\title{
Konfigurasi Komunikasi Politik atas Fenomena Calon Tunggal Pada Pilkada Kabupaten Kediri Tahun 2020
}

\author{
Prilani, Setio Budi H. Hutomo
}

Program Studi Komunikasi dan Penyiaran Islam IAIN Kediri, Jl. Sunan Ampel no 7, Ngronggo, Kota Kediri, Indonesia dan Program Studi Ilmu Komunikasi Universitas Atma Jaya Yogyakarta,

Jl. Babarsari no 6, Sleman, DIY, Indonesia.

duta86@yahoo.com,setioobudi@gmail.com

Masuk tanggal : 14-10-2020, revisi tanggal : 01-12-2020, diterima untuk diterbitkan tanggal : 02-12-2020

\begin{abstract}
The phenomenon of a single candidate in simultaneous regional elections in Indonesia has occurred since 2015. In 2018 there were 18 regional elections with a single candidate and 25 regions in 2020. The implementation of simultaneous regional elections in Kediri district in 2020 was marked by the presence of a single candidate is interesting to study more, because it is new. The main question in this research is why there is phenomenon a single candidate in the Kediri district election and how is the configuration of political communication for the emergence of a single candidate. The purpose of this study was to determine the process of the phenomenon emergence of a single candidate in the Kediri district election and to determine the configuration of political communication for the emergence of a single candidate. This research uses a case study approach by describing political facts in the field. Research informants are consisted of election administrators, members of political parties, academicians and community leaders. The results showed that the occurrence of a single candidate in the Kediri district was because all political parties provided support for 1 pair of candidates. This political fact is marked by the configuration of political communication through the recommendation of political parties from the central leadership council (DPP). Even though there has been a selection of prospective pairs of candidates at the regional level (DPC DPD), the transactional communication by candidatos uses an approach with a number of political party officials both at the regional and central levels. The recommendation of this research is to change the regulations to avoid the single candidate appear in the next regional election., especially the minimum requirement for support from candidates and the proposal to be returned to the election by DPRD members therefore would generate truly regional representatives.
\end{abstract}

Keywords: configuration, local election, political communication, single candidate

\begin{abstract}
Abstrak
Fenomena calon tunggal pada pilkada serentak di Indonesia telah terjadi sejak tahun 2015 dengan 3 pasangan calon tunggal. Pada tahun 2018 terdapat 18 pilkada dengan calon tunggal hingga tahun 2020 ada sejumlah 25 daerah yang memiliki calon tunggal. Pelaksanaan pilkada serentak di kabupaten Kediri tahun 2020 diwarnai dengan hadirnya calon tunggal sehingga menarik untuk dikaji lebih mendalam karena merupakan fenomena baru bagi proses demokrasi di kabupaten Kediri. Masalah dalam penelitian ini, mengapa terjadi fenomena calon tunggal pada pilkada kabupaten Kediri dan bagaimana konfigurasi komunikasi politik atas munculnya calon tunggal pada pilkada kabupaten Kediri. Tujuan
\end{abstract}


dari penelitian ini untuk mengetahui proses munculnya fenomena calon tunggal pada pilkada kabupaten Kediri dan untuk mengetahui konfigurasi komunikasi politik atas munculnya calon tunggal pada pilkada kabupaten Kediri. Penelitian ini menggunakan pendekatan studi kasus dengan mendeskripsikan fakta politik dilapangan. Informan penelitian terdiri dari penyelenggara pilkada, anggota partai politik, akademisi dan tokoh masyarakat. Hasil penelitian menunjukan bahwa terjadinya calon tunggal pada pilkada kabupaten Kediri tahun 2020 karena semua partai politik memberikan dukungan kepada 1 pasangan calon. Calon perseorangan tidak mampu memenuhi jumlah minimal dukungan yang dipersyaratkan. Fakta politik ini ditandai dengan adanya konfigurasi komunikasi politik melalui rekomendasi partai politik dari dewan pimpinan pusat (DPP). Meski sudah dilakukan penjaringan bakal pasangan calon di tingkat daerah/cabang (DPC/DPD). Komunikasi trasaksional oleh calon menggunakan pendekatan dengan sejumlah pengurus partai politik baik ditingkat daerah maupun pusat. Rekomendasi dari penelitian ini adalah perubahan peraturan agar tidak muncul calon tunggal pada pilkada selanjutnya terutama syarat minimal dukungan calon perseorangan serta usulan pemilihan kepala daerah dikembalikan kepada pemilihan oleh anggota DPRD. Rekomendasi ini diharapkan dapat memunculkan beberapa calon kepala daerah yang benar-benar merupakan representasi daerah.

Kata Kunci: calon tunggal, komunikasi politik, konfigurasi, Pilkada

\section{Pendahuluan}

Pemilihan kepala daerah serentak di Indonesia akan diadakan pada tanggal 9 Desember 2020 di 270 daerah merupakan perhelatan demokrasi. Provinsi Jawa Timur akan menggelar pilkada serentak di 19 Kabupaten dan Kota. Pilkada langsung, sebagai bagian dari perbaikan proses demokrasi pasca era reformasi, merupakan proses penguatan dan pendalaman demokrasi serta upaya untuk mewujudkan tata kelola pemerintahan yang baik dan efektif, Sarjan dkk (2020) menyebut persoalan adanya penyusupan kepentingan modal, pemilih sangat pragmatis (serangan fajar), konflik horizontal sampai penyalah gunaan APBD. Hanafi (2014) menekankan bahwa meskipun pilkada langsung telah menggeser kekuasaan DPRD menjadi kekuasaan rakyat dalam memilih calon pemimpin daerah, pada praktiknya banyak ditemukan kekecewaan atas kualitas pilkada langsung, untuk menggambarkan bahwa selain memiliki kelebihan secara substantif, juga kelemahan sampai di tingkat praktis lapangan. Demikian pula akses terhadap pemerintahan, menurut Fachrurozi (2016) hanya dimiliki oleh orang/ calon/ petahana yang memiliki modal/ akses modal, oleh karenanya proses politik akan dikuasai oleh segelintir orang.

Dalam perkembangan dinamika politik di Indonesia pada dekade terakhir ini, salah satu fenomena yang menarik adalah munculnya calon tunggal. Pada Pilkada tahun 2015 terdapat 3 calon tunggal dan menurut catatan KPU meningkat signifikan menjadi 25 daerah kabupaten maupun kota di Pilkada serentak tahun 2020 ini, menjadi sejarah tersendiri bagi kehidupan demokrasi kita, sebagaimana terlihat pada bagan dibawah ini : 


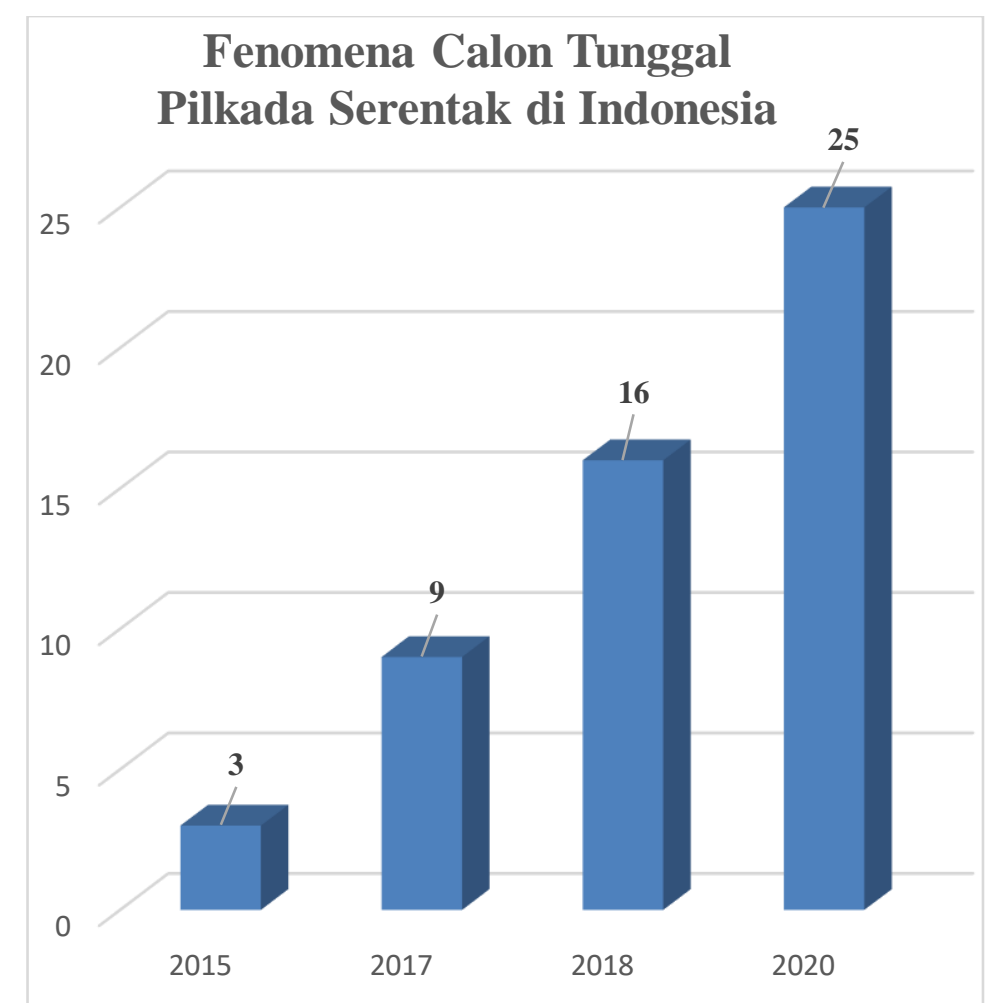

Bagan 1 : Jumlah Pasangan Calon Tunggal Dari Tahun 2015 - 2020

Sumber : Nasional.Kompas.Com (2020), Bawaslu (2018)

Spekulasi bermunculan akibat adanya fenomena calon tunggal ini. Persoalan kaderisasi partai politik ditengarai sebagai faktor utama. Belum lagi anggapan bahwa mencalonkan diri dalam kontestasi pilkada membutuhkan mahar yang sangat mahal. Disisi lain adanya orang kuat yang melakukan akrobat politik dengan memborong semua rekomendasi partai politik. Harahap (2016) mengatakan bahwa pilkada serentak tahun 2015 dipandang minim pasangan calon, terutama karena yang berkompetisi sangat sedikit jumlahnya, probabilitas berkurang jadi calon berkurang. Salah satu faktor yang menyebabkan adalah aspek regulasi / peraturan, berkenaan dengan persyaratan pencalonan.

Uji materi terhadap undang-undang nomor 8 tahun 2015 tentang perubahan atas UU No.1 tahun 2015 tentang penerapan peraturan pemerintah pengganti undang-undang No. 1 tahun 2014 tentang pemilihan Gubernur, Bupati dan Walikota menjadi undang-undang pilkada dengan materi gugatan syarat minimal dua pasang calon dalam pilkada. Setelah melalui gugatan maka Mahkamah Konstitusi memutuskan harus ada lawan tanding dari pasangan calon tunggal dan selanjutnya diatur oleh undang-undang no. 10 tahun 2016 tentang persyaratan calon kepala daerah. Faktanya, perubahan aturan ini justru membuat peningkatan jumlah calon tunggal.

Kabupaten Kediri memiliki luas wilayah 1.386 .05 km dengan 26 kecamatan yang tersebar pada 343 desa dan 1 kelurahan dengan jumlah penduduk 1.571.555 jiwa. Sedangkan Daftar Pemilih Sementara (DPS) sejumlah 1.234.918 jiwa. Berdasarkan pemilihan calon legislatif pada pemilu tahun 2019 maka terdapat 50 
kursi di DPRD Kabupaten Kediri yang berasal dari 9 partai politik. Menurut undang undang-undang nomor 10 tahun 2016 tentang pilkada yang dijabarkan dalam peraturan KPU nomor 1 tahun 2020 maka syarat pencalonan kepala daerah harus mendapatkan minimal $20 \%$ dari jumlah kursi di DPRD. Dengan jumlah 50 kursi di DPRD kabupaten Kediri maka jumlah minimal kursi untuk dapat mengusung calon bupati adalah 10 kursi. Berikut ini tabel jumlah kursi DPRD kabupaten Kediri;

Tabel 1. Perolehan Kursi Parpol DPRD Kabupaten Kediri

\begin{tabular}{|c|c|c|}
\hline No & Partai Politik & Perolehan Kursi \\
\hline 1 & PDI-Perjuangan & 15 \\
\hline 2 & PKB & 9 \\
\hline 3 & Partai Golkar & 6 \\
\hline 4 & PAN & 5 \\
\hline 5 & Partai Gerindra & 5 \\
\hline 6 & Partai Nasdem & 4 \\
\hline 7 & Partai Demokrat & 3 \\
\hline 8 & PPP & 2 \\
\hline 9 & PKS & 1 \\
\hline & Total Jumlah Kursi & 50 \\
\hline
\end{tabular}

Berdasar data tabel di atas maka dimungkinkan jumlah pasangan bakal calon bupati minimal 3 pasangan. PDI Perjuangan sebagai satu-satunya partai politik yang dapat memunculkan calon sendiri tanpa koalisi partai politik lain. Fenomena menarik dalam pilkada di Kabupaten Kediri dengan munculnya sebuah kejutan ketika muncul sosok Hanindhito Himawan Pramono yang tak lain anak sulung Menteri Sekretaris Kabinet Republik Indonesia untuk mengikuti kontestasi. Meski diklaim menjadi representasi PDI Perjuangan, sosok Hanindhito Himawan Pramono juga diisukan akan memborong semua kursi partai politik di DPRD kabupaten Kediri.

Munculnya calon tunggal pada pilkada kabupaten Kediri merupakan fenomena baru, karena selama ini belum pernah terjadi calon tunggal pada perhelatan pilkada kabupaten Kediri. Ini yang mendasari banyak kritikan kepada pihak-pihak yang seolah olah akan mendesain adanya calon tunggal pada pilkada kabupaten Kediri. Bahkan terdapat perlawanan dengan mengkampanyekan untuk memilih bumbung kosong atau kolom kosong. Rangkaian peristiwa tersebut menjadi bahan kajian yang menarik untuk diteliti.

Berangkat dari fenomena di atas, maka fokus penelitian ini adalah mengapa terjadi fenomena calon tunggal pada pilkada kabupaten Kediri dan bagaimana konfigurasi komunikasi politik atas munculnya calon tunggal pada pilkada kabupaten Kediri. Tujuan dari penelitian ini untuk mengetahui proses munculnya fenomena calon tunggal pada pilkada kabupaten Kediri dan untuk mengetahui konfigurasi komunikasi politik atas munculnya calon tunggal pada pilkada kabupaten Kediri. 
Banyaknya kritik kepada pihak-pihak yang seolah olah akan mendesain adanya calon tunggal pada pilkada kabupaten Kediri merupakan dinamika politik. Rangkaian peristiwa politik tersebut menjadi bahan kajian yang menarik untuk diteliti dan diharapkan dapat memberikan solusi atas persoalan calon tunggal pada pilkada serentak selanjutnya. Disisi lain, konfigurasi politik dalam proses munculnya calon tunggal pada pilkada kabupaten Kediri juga dapat memberikan pemahaman baru atas kajian komunikasi politik dengan adanya dinamika perhelatan pilkada di Indonesia.

\section{Konfigurasi Politik}

Konfigurasi politik akan memberi warna dominan terhadap pengisian struktur pembuat keputusan. Dalam pemilihan kepala daerah tentu konfigurasi politik tergantung kepada jumlah partai yang disediakan secara legitimasi atau yang ditetapkan oleh undang-undang. Kompleksitas persoalan sejumlah besar partai adalah dengan hadirnya dinamika politik, dan didalamnya tentu proses komunikasi politik.

Sebagai komunikator utama politik, dalam melaksanakan tugas dan fungsinya perlu merujuk kepada dua konsep utama. Pertama, konsep yang ada kaitannya dengan bangun (struktur) kerja. Di dalam perangkat pembuat keputusan, infomasi ditangani dan dikelola oleh struktur-struktur yang mengembangkan ingatan (memory), nilai-nilai dan pusat-pusat pembuat keputusan substantif. Kedua, kemampuan mengurai serangkaian arus informasi yang terpola secara bersamaan dan membentuk suatu jaringan sekaligus mendapat dukungan dilegislatif.

Simbol-simbol komunikasi berada pada elit kekuasaan, sebagai konsekuensinya partai-partai politik yang duduk dalam legislatif dapat berperan sebagai pendukung maupun oposan yang dapat menggoyahkan pengelolaan pemerintahan. Hal ini memberikan suatu gambaran bahwa konfigurasi politik memberi dampak tajam terhadap pengisian struktur kekuasaan dengan sistem kepartaian. Mafud MD (1999) menjabarkan pokok-pokok konseptual dalam konfigurasi politik, mencakup : Konfigurasi Politik Demokratis dan Konfigurasi Politik Otoriter. Perbedaan mendasar 2 konsep tersebut adalah posisi kemampuan dalam potensi dan intervensi untuk mempengaruhi kebijakan politik, dalam artian luas, termasuk menentukan figur pemimpin. Sedangkan menurut Prayudi (2013) posisi birokrasi sebagai kekuatan politik cenderung masih mengalami transisi democratic governance ditingkat lokal daripada sekedar executive ascendancy atau alat politik kekuasaan, sehingga dalam kasus pilkada diperlukan suatu komitmen dan dukungan kuat untuk konteks pembangunan politik, terutama konsep sebagai pelayanan publik, aspek profesionalisme kerja dan integritas.

Konfigurasi politik ini ditandai dengan dorongan elit kekuasaan untuk melakukan pilihan-pilihan dengan proses komunikasi politik. Sedangkan komunikasi politik yang dibangun dapat menggunakan metode transaksional. Konfigurasi politik pada hakekatnya dalah proses legitimasi kehadiran partai politik sebagai salah satu unsur insfrastruktur politik. Legitimasi sebagai pengakuan keberadaan partai dalam lingkup kehidupan negara melalui instrumen berbagai produk kebijakan politik. 


\section{Komunikasi Politik}

Pendekatan komunikasi politik memandang bahwa tugas pemerintah (elit berkuasa) dan politik dalam arti sebagai suatu proses pengendalian dan koordinasi semua unsur yang ada dalam lingkup pemerintahan. Pada situasi tertentu komunikasi politik lebih menekankan pada proses pembuatan keputusan ketimbang memikirkan dampak dari keputusan atau kebijakan yang dibuat. Proses ini merupakan mekanisme untuk mencapai serangkaian tujuan, terutama dalam mewadahi simbol-simbol kepentingan masyarakat dan simbol-simbol kepercayaan masyarakat atas simbol-simbol kekuasaan. Perloff (2017) menyebut komunikasi politik sebagai aktivitas komunikasi yang kompleks, melibatkan banyak faktor dan komponen, mulai dari bahasa dan simbol, dengan aktor : pemimpin, media, masyarakat, serta kelompok masyarakat, dengan target multi efek pada individu dan masyarakat dan berkaitan dengan kebijakan publik, negara sampai komunitas.

Sementara dalam memaknai keterlibatan demokratis dalam politik Kaid (2004) sebagian besar teori dan penelitian komunikasi politik menjelaskan aspek dari kepatuhan terhadap norma dan nilai demokrasi sampai pada perilaku yang dirancang untuk mempengaruhi kualitas hidup masyarakat. John (2016) menjelaskan pada saat yang sama, bagaimana hubungan budaya popular dengan komunikasi politik menarik perhatian kita pada keragaman cara dimana budaya popular didefinisikan disini dari segi keinginannya untuk menghibur daripada menginformasikan, mengungkapkan sikap dan nilai-nilai politik. Nugraha dan Puspitasari (2018) meneliti kampanye Pilihan Gubernur DKI tahun 2017, dimana pasangan Basuki Tjahaya Purnama dan Djarot Saiful Hidayat dinilai lebih mengedepankan kampanye yang logis dan rasional disertai dengan bukti (track record), berhadapan dengan masa pemilih kandidat lain yang menggunakan aspek emosional. Susanto (2013) mencatat bahwa komunikasi politik yang menyentuh kebutuhan masyarakat secara mendasar akan meningkatkan partisipasi masyarakat dalam kegiatan politik. Disini problem muncul karena komunikasi politik, seperti diberbagai kegiatan pemilihan legislatif maupun eksekutif, lebih banyak aspek emosional daripada rasional, sebagaimana yang disampaikan Gazali (2004) mengenai era reformasi yang berimplikasi pemilu langsung dan tiba-tiba saja komunikasi politik Indonesia mengalami sebuah lompatan lain ke dalam "politik citra"

Pertanyaan penting dalam konteks pilkada dengan calon tunggal adalah bagaimana memahami komunikasi politik yang terjadi. Romli (2018) mencatat tentang komunikasi politik yang timpang, yaitu, prinsip equel playing battle field atau arena persaingan yang setara tidak terjadi, ini menyangkut fairness dalam komunikasi, terutama bagaimana kesempatan waktu dan tempat/ hak kampanye bagi pendukung kotak kosong/Kolom Kosong, termasuk proses kampanye dan debat politik antara lawan debat bagi calon tunggal dan kelompok Kotak Kosong.

\section{Teori Hegemoni}

Hegemoni dalam pengertian Gramsci adalah sebuah organisasi konsensus dimana ketertundukan diperoleh melalui penguasaan ideologi dari kelas yang menghegemoni. Gramsci memperluas pengertian hegemoni Lenin, sehingga hegemoni juga mencakup peran kelas kapital dan anggotanya, baik dalam merebut 
Prilani, Setio Budi H. Hutomo: Konfigurasi Komunikasi Politik atas Fenomena Calon Tunggal Pada Pilkada Kabupaten Kediri Tahun 2020

kekuasaan negara maupun dalam mempertahankan kekuasaan yang sudah dimiliki. Selanjutnya, jika bagi Lenin hegemoni utamanya dipahami dalam pengertian aliansi antar kelas atau kelompok kelas, maka Gramsci menambahkan dimensi nasional kerakyatan dalam konsep hegemoni Gramsci. Roger Simon. (2012).

Gramsci menyatakan bahwa suatu kelas tidak dapat meraih kepemimpinan nasional dan menjadi hegemonik, jika kelas itu hanya memperhatikan kepentingan mereka sendiri, karenanya mereka harus juga memperhatikan tuntutan dan perjuangan rakyat yang tidak mempunyai karakter kelas yang bersifat murni, yaitu kepentingan yang tidak muncul secara langsung dari hubungan-hubungan produksi. Dengan demikian, hegemoni mempunyai dimensi kelas dan dimensi nasional kerakyatan. Menurut Gramsci (2012) ada dua poin penting, yaitu hegemoni moral dan intelektual. Pada prakteknya berbagai lembaga/organisasi menjadi pelaksana proses hegemoni, apakah melalui konten moralitas, demikian pula intelektualitas, secara terpisah atau bersama, tentu dengan tujuan (misal politik) yang telah ditentukan oleh sekelompok elit yang memiliki kuasa hegemonic tersebut.

Pemikiran Gramsci membukakan kesadaran tentang gerakan pekerja sebagai bagian dari gerakan masyarakat sipil (civil society) dan sebaliknya.Titik awal konsep Gramsci tentang hegemoni adalah bahwa suatu kelas dan anggotanya menjalankan kekuasaan terhadap kelas-kelas di bawahnya dengan cara kekerasan dan persuasi. Hegemoni bukan hubungan dominasi dengan menggunakan kekuasaan, tetapi hubungan persetujuan dengan mengunakan kepemimpinan politik dan ideologis. Ideologi partai politik misalnya meskipun berbeda-beda tetapi jika mendapat persetujuan atau konsensus dari yang lain maka akan membentuk persetujuan dengan mengedepankan kepentingan politik melalui pendekatan moral ataupun intelektual.

Menurut Shugart dan Lipjphart (dalam Chaniago, 2016) jika penyelenggaraan pemilu eksekutif diserentakkan (simultan) dengan pemilu legislatif akan menimbulkan coottail effect, yaitu (hasil) pemilihan eksekutif akan mempengaruhi (hasil) pemilihan anggota legislatif. Sehingga jika kasusnya misalnya pemilihan presiden, maka pemilih presiden akan sekaligus/ cenderung memilih partai pendukungnya. Menjadi menarik jika dibandingkan dengan proses konfigurasi dan komunikasi politik yang "normal" berlangsung, yaitu kontestasi dengan beberapa calon, sebagaimana Aspinall dan Berenschot (2020) bahwa pada pemilu dan terutama pilkada, telah bergeser dari "perang udara", yaitu berbagai kegiatan kampanye melalui media dan kegiatan yang melibatkan massa yang besar ke "perang darat", terutama pada detik-detik kepastian kemana suara pemilih akan ditentukan. Ditambah lagi dengan terminologi "serangan fajar" yang sering digambarkan dengan aktivitas "pembelian suara" pemilih kepada calon atau kandidat tertentu. Calon tunggal tentu tidak bisa digambarkan sebagai suatu peristiwa alamiah, tentu melalui proses politik yang panjang dan rumit sehingga bisa diduga terencana, terutama jika berbagai stakeholder sebenarnya tidak sepakat secara utuh. 


\section{Regulasi Calon Tunggal Pilkada}

Pemilihan kepala daerah pada dasarnya adalah untuk melahirkan pemimpin di daerah yang kuat secara politik dan profesional. Namun demikian grafik menunjukan terdapat peningkatan signifikan atas jumlah calon tunggal yang berkontestasi didaerah diantara kurun waktu tahun 2015 sampai tahun 2020 Kompas (2020). Regulasi yang dibuat ternyata belum mampu menekan jumlah calon tunggal pilkada di Indonesia. Berikut ini runtutan aturan main pilkada dengan calon tunggal ;

Tabel 2. Regulasi Calon Tunggal Pilkada

\begin{tabular}{|c|c|c|}
\hline Produk Hukum & Konten & Implikasi \\
\hline UU No. 8 Tahun 2015 & $\begin{array}{l}\text { Melegalkan pasangan calon } \\
\text { tunggal dalam pilkada }\end{array}$ & $\begin{array}{l}\text { Adanya solusi atas } \\
\text { kebuntuan proses pilkada } \\
\text { jika yang mendaftar hanya } \\
\text { calon tunggal }\end{array}$ \\
\hline UU No. 10 Tahun 2016 & $\begin{array}{l}\text { Mensyaratkan minimal } 2 \\
\text { pasangan calon kepala } \\
\text { daerah dalam kontestasi } \\
\text { pilkada dengan } \\
\text { menggunakan } 2 \text { kolom yang } \\
\text { terdiri dari pasangan calon } \\
\text { dan kolom kosong yang } \\
\text { tidak bergambar dengan cara } \\
\text { mencoblos }\end{array}$ & $\begin{array}{l}\text {-Memutuskan pilkada } \\
\text { tetap dilaksanakan meski } \\
\text { hanya dengan calon } \\
\text { tunggal } \\
\text {-Pasangan calon bisa } \\
\text { dinyatakan menang jika } \\
\text { mendapat suara lebih dari } \\
50 \% \\
\text { - Ketentuan lbh lanjut } \\
\text { akan diatur dengan PKPU }\end{array}$ \\
\hline 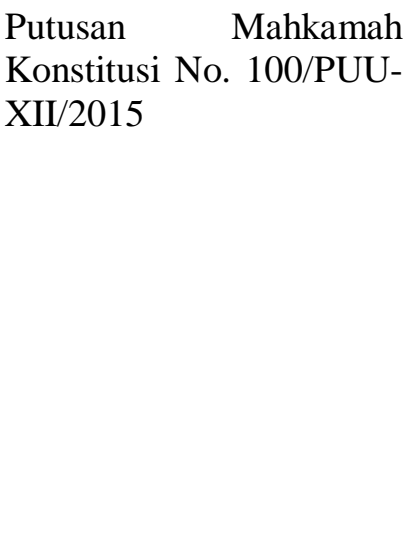 & $\begin{array}{l}\text { Daerah dengan calon } \\
\text { tunggal, hanya ada pilihan } \\
\text { setuju atau tidak setuju }\end{array}$ & $\begin{array}{l}\text { Adopsi dari Pasal } 54 \text { C UU } \\
\text { No. } 10 \text { Tahun } 2016 \\
\text { menyatakan pemilihan } \\
\text { pasangan calon tunggal } \\
\text { bisa dilaksanakan jika } \\
\text { setelah penundaan dan } \\
\text { memperpanjang } \\
\text { pendaftaran tetap hanya } \\
\text { ada satu pasangan bakal } \\
\text { calon dan memenuhi } \\
\text { syarat maka pilkada akan } \\
\text { tetap dilanjutkan }\end{array}$ \\
\hline $\begin{array}{lr}\text { Perubahan } & \text { Putusan } \\
\text { Mahkamah } & \text { Konstitusi } \\
\text { No. } 2 \text { tahun } & 2015 \text { menjadi } \\
\text { Perubahan } & \text { Putusan } \\
\text { Mahkamah } & \text { Konstitusi } \\
\text { No. } 2 \text { tahun } 2017\end{array}$ & $\begin{array}{l}\text { Mengatur siapa yang } \\
\text { memiliki kedudukan hukum } \\
\text { (legal standing) mengajukan } \\
\text { gugatan sengketa pilkada } \\
\text { dalam hal ada satu pasangan } \\
\text { calon dalam pilkada. }\end{array}$ & $\begin{array}{l}\text { Pengajuan kembali ke } \\
\text { mahkamah konstitusi jika } \\
\text { terjadi perselisihan } \\
\text { perolehan suara }\end{array}$ \\
\hline
\end{tabular}

Dari tabel di atas menunjukan bahwa betapa peraturan yang dibuat selalu muncul persoalan baru. Selain itu, undang-undang pemilu juga mengalami beberapa revisi karena harus menyesuaikan kondisi yang ada dilapangan. Sengketa pilkada seringkali muncul akibat ketidakjelasan aturan yang mengatur karena 
munculnya sengketa akibat tidak termaktub dalam undang-undang atau peraturan yang menjadi turunannya.

Calon tunggal dalam pilkada juga mengalami beberapa sengketa atas aturan yang ada. Persoalan muncul akibat dari perdebatan apakah kalau calon tunggal bisa dikatakan sebagai kontestasi. Disisi lain, adanya angapan bahwa jikalau terjadi hanya 1 pasangan calon yang mendaftar sampai durasi waktu yang tidak bisa diprediksi maka akan menghasilkan kepala daerah yang tidak demokratis. Regulasi harus dibuat meskipun dengan konsekuensi tertentu, akan tetapi pilihan-pilihan dimungkinkan tidak bisa memuaskan semua pihak.

Gunawan dkk (2020) menyebut bahwa Pemilihan Kepala Daerah (Pilkada) yang merupakan produk era reformasi tak jarang kerap menghadirkan kejutan dalam setiap perhelatannya. Sebut saja misalnya, fenomena pasangan calon tunggal hingga politik dinasti. Bagi Romli (2018), problematika pilkada dengan calon tunggal merujuk pada kepentingan petahana (status quo) dan partai politik (kemenangan dan elektabilitas calon), sisi lain adalah tingginya biaya politik, sehinga calon independen misalnya akan kesulitan berpartisipasi. Termasuk dalam analisisnya adalah adanya kegagalan kaderisasi partai dan krisis kepemimpinan didaerah. Catatan Romli tersebut menjadi penting, yaitu, pemilihan kepala daerah yang hanya diikuti oleh satu pasangan calon, manifestasi kontestasinya lebih tepat apabila dipadankan dengan plebisit yang meminta rakyat (pemilih) untuk menentukan pilihannya apakah "Setuju" atau "Tidak Setuju" dengan pasangan calon tersebut, bukan dengan Pasangan Calon Kotak Kosong, sebagaimana dikonstruksikan oleh Pemohon.

\section{Metode Penelitian}

Peneliti menggunakan pendekatan studi kasus. Pendekatan ini dipilih karena studi kasus adalah studi empiris yang menyelidiki fenomena kontemporer dalam konteks kehidupan nyata sehingga fokus penelitian ini yang mengkaji persoalan kontemporer tentang calon tunggal. Metode ini juga memungkinkan peneliti untuk menjelaskan secara deskriptif apa yang terjadi atas fenomena calon tunggal pada pilkada kabupaten Kediri tahun 2020.

Menurut Yin (2009), metode penelitian studi kasus merupakan strategi yang tepat untuk digunakan dalam penelitian yang menggunakan pokok pertanyaan penelitian "How atau Why", sedikit waktu yang dimiliki peneliti untuk mengontrol peristiwa yang diteliti dan fokus penelitiannya adalah fenomena kontemporer untuk melacak peristiwa kontemporer. Pada metode studi kasus, peneliti fokus kepada desain dan pelaksanaan penelitian. Pertanyaan dalam penelitian ini adalah mengapa terjadi fenomena calon tunggal pada pilkada kabupaten Kediri tahun 2020 dan bagaimana konfigurasi komunikasi politik yang terjadi pada pilkada kabupaten Kediri tahun 2020.

Penelitian ini dilakukan mulai 15 Juli sampai dengan pendaftaran dan penetapan calon tanggal 23 September 2020. Objek penelitian ini adalah konfigurasi komunikasi politik atas fenomena calon tunggal. Peneliti menentukan beberapa kriteria dalam penentuan sejumlah 20 informan, yakni ; Penyelenggara Pilkada, Komisioner KPUD Kabupaten Kediri, Komisioner Bawaslu Kabupaten 
Kediri. Peneliti juga mewawancarai informan Partai Politik dari PDIP, Nasdem, PKS dan PPP serta Perindo (Partai Non Parlemen). Selain itu, peneliti juga melakukan wawancara dengan 5 orang akademisi (IAIN Kediri, UNP Kediri, Uniska Kediri dan UNIK Kediri untuk melihat dalam prespektif teoritis. Peneliti juga mewawancarai 7 tokoh masyarakat dari Nahdatul Ulama, Asosiasi Perkumpulan Kepala Desa (PKD), NGO, Mantan Ketua DPRD, Pengusaha, Wakil Bupati Aktif.

Data diperoleh dengan melakukan wawancara mendalam tanpa diketahui oleh informan dengan harapan terdapat originalitas jawaban dari informan yang sudah diketahui kriterianya, yakni ; penyelenggara pilkada, anggota partai politik, akademisi dan tokoh masyarakat.

Untuk keabsahan data, peneliti melakukan triangulasi sumber dengan mengkonfrontasi kembali interpretasi peneliti kepada para informan atas data yang diperoleh pada saat wawancara. Selain itu trianggulasi juga dilakukan kepada informan yang mengikuti penjaringan ditingkat Dewan Pimpinan Cabang Partai Politik Kabupaten Kediri.

\section{Hasil Penemuan dan Diskusi}

Dari hasil wawancara di lapangan, rata-rata informan menyatakan keberatan dengan munculnya calon tunggal. Mereka beranggapan kontestasi diperlukan lawan bukan dengan bumbung kosong. Demokrasi juga mengamanatkan bahwa perlu ada kontestasi, pemberlakuan UU 10 tahun 2016 yang mengalami revisi setelah digugat di Mahkamah Konstitusi atas UU No. 8 tahun 2015 ternyata tidak mampu menghentikan adanya calon tunggal dalam perhelatan pilkada serentak.

Temuan peneliti ini memaknai adanya penurunan nilai demokrasi pada pilkada serentak di kabupaten Kediri. Beberapa informan mencontohkan bahwa apa yang dilakukan oleh partai politik adalah komunikasi instan yang tidak melihat jauh kedepan fungsi dan tugas partai politik. Kemunculan calon tunggal tidak saja membuat masyarakat tidak nyaman tapi akan mempengaruhi kualitas demokrasi kedepan. Hasil temuan penelitian ini diklasifikasikan menjadi 2 bagian sesuai dengan fokus masalah dalam penelitian, yakni ; Fenomena Calon Tunggal pada Pilkada Kabupaten Kediri dan Konfigurasi Komunikasi Politik atas munculnya Calon Tunggal Pilkada Kabupaten Kediri tahun 2020.

\section{Fenomena Calon Tunggal pada Pilkada Kabupaten Kediri}

Munculnya calon tunggal pilkada kabupaten Kediri diawali dengan drama politik yang luar biasa. Fase awal, beberapa tokoh memunculkan nama jauh-jauh hari sebelum tahapan pilkada. Para kandidat telah mencuri start kampanye dengan pemasangan baliho dan iklan-iklan di media massa maupun media luar ruang, belum lagi dimedia sosial yang dijalankan oleh tim sukses mereka. Fenomena mulai menghangat setelah mantan bupati Sutrisno mengundurkan diri dari jabatan sebagai ketua DPC PDIP kabupaten Kediri. Realitas ini membuat peta politik menjadi cair, mengingat dominasi dinasti bupati Sutrisno berkuasa selama 20 tahun dengan bendera partai politik PDIP juga sangat luar biasa. 
Prilani, Setio Budi H. Hutomo: Konfigurasi Komunikasi Politik atas Fenomena Calon Tunggal Pada Pilkada Kabupaten Kediri Tahun 2020

Fase berikutnya, muncul nama-nama yang akan mengikuti kontestasi dengan strategi pemasaran politik masing-masing. Setelah beredar nama-nama calon bupati maupun wakil bupati selanjutnya mereka mengikuti penjaringan di tingkat Dewan Pimpinan Daerah/Cabang. Kontestasi mulai menghangat ketika para pengurus partai politik tidak segera memberikan keputusan rekomendasi dengan dasar bahwa keputusan ada ditangan DPP. Disisi lain, aturan partai politik memang memberikan ruang kepada calon pemimpin daerah mendaftarkan diri di tingkat daerah, provinsi maupun pusat.

Persoalan mulai muncul ketika dua partai besar memberangkatkan pasangan calon fenomenal, yakni Hanindhito Himawan Pramana yang merupakan representasi PDIP dan Dewi Maria Ulfa dengan rekomendasi dari PKB. Akar persoalan pasangan calon ini muncul dari rekomendasi DPP. Hal ini dianggap mencederai proses penjaringan yang sudah dilaksanakan di daerah bahkan dari awal PKB sudah mendeklarasikan pasangan nama. Konflik semakin menjadi ketika rekomendasi atas nama Hanindhito Himawan Pramana dan Dewi Maria Ulfa secara resmi turun dan di serahkan kepada yang bersangkutan.

PDIP sebagai partai politik yang memberikan rekomendasi kepada Hanindhito Himawan Pramana dianggap sebagai kewajaran karena dominasi figur Pramono Anung Wibowo selaku Menteri Sekretaris Kabinet yang juga merupakan ayah kandung Hanindhito Himawan Pramana. Persoalan mulai muncul pasca rekomendasi PKB kepada Dewi Maria Ulfa yang dianggap bukan representasi Nahdatul Ulama (NU). Penolakan mulai menguat ditengah rekomendasi PKB kepada Dewi Maria Ulfa, hal ini didasari pada roh PKB adalah Nahdatul Ulama (NU) sehingga semua kebijakan yang muncul harus dimusyawarahkan secara nonformal kepada kyai-kyai dan tokoh-tokoh Nahdatul Ulama (NU).

Fenomena ini terus berlanjut karena persyaratan untuk mendaftarkan pasangan calon harus minimal 10 kursi di DPRD Kabupaten Kediri. Selanjutnya partai politik yang lain mulai mengikuti arus besar dengan memberikan rekomendasi kepada pasangan Hanindhito Himawan Pramana dan Dewi Maria Ulfa. Nasdem, Golkar dan PAN kemudian menjadi partai yang masuk koalisi. Setelah melalui negosiasi, Partai Gerindra, Partai Demokrat merapat sebagai partai yang masuk koalisi selanjutnya. Sedangkan PKS dan PPP yang semula akan mengusung sendiri calon atau bahkan abstain ternyata pada detik-detik akhir juga menyatakan diri bergabung pada koalisi besar ini.

Dari tahapan wawancara yang peneliti lakukan, terdapat pro dan kontra diantara informan. Penyelenggara pilkada yakni, KPUD dan Bawaslu tentu berpijak pada aturan normatif dimana calon tunggal adalah sah menurut undang-undang dan calon tunggal juga akan mempunyai lawan kolom kosong. Secara yuridis adanya calon tunggal tidak melawan konstruksi hukum yang dibangun. Persolannya jika terjadi ketidak-berimbang kekuatan calon tunggal melawan kolom kosong apakah yang harus dilakukan. Belum lagi persoalan netralitas ASN yang disinyalir mendukung kepada calon tunggal.

Sedangkan tokoh masyarakat yang memberikan jawaban atas wawancara malah menyuarakan kembali pada aturan awal bahwa pilkada dilakukan oleh DPRD karena besaran biaya pilkada yang hampir menembus angka 70 milyar rupiah. Di sisi lain, informan beranggapan bahwa jika terjadi calon tunggal maka 
sudah seharusnya ada evaluasi menyeluruh terhadap proses tahapan pilkada berikut undang-undang dan peraturan terkait. Selain itu, terdapat anggapan bahwa calon tunggal yang tidak merepresentasikan kepentingan masyarakat kabupaten Kediri secara luas juga akan berdampak pada ketidaknyamanan publik.

\section{Konfigurasi Komunikasi Politik atas munculnya Calon Tunggal}

Prespektif kalangan partai politik terhadap munculnya calon tunggal sangat bervariasi dengan melihat berbagai kepentingan. Partai politik merasa tidak akan bisa melawan kekuatan dominan PDIP 15 kursi di DPRD Kabupaten Kediri. Sedangkan partai politik lain menjadikan momentum pilkada ini sebagai rutinitas karena merasa rekomendasi dari DPD maupun DPC tidak akan ada artinya kalau tidak berbanding lurus dengan keputusan DPP. Salah satu ketua DPC yang berusaha abstain ternyata juga tidak bisa menolak keputusan rekomendasi dari DPP. Inilah yang menunjukan bahwa kekuatan elit politik kekuasaan tertingi jika melakukan konfigurasi politik dengan pengoptimalan pada jaringan komunikasi yang mereka bentuk maka tidak akan ada perlawanan dari pihak lain.

Berikut ini tabel hasil wawancara dengan informan yang dapat dilihat dan jelaskan dalam konteks konfigurasi komunikasi politik, yaitu ;

Tabel 3. Perbandingan Informan atas Fenomena Calon Tunggal

\begin{tabular}{|c|c|c|c|}
\hline Informan & Jmlh & Konfigurasi Politik & Komunikasi Politik \\
\hline $\begin{array}{l}\text { Penyelenggara } \\
\text { Pilkada }\end{array}$ & 2 & $\begin{array}{l}\text { - Melaksanakan pilkada } \\
\text { dengan tahapan-tahapan } \\
\text { sesuai undang-undang } \\
\text { maupun turunannya } \\
\text { - Melakukan pengawasan } \\
\text { terhadap pelanggaran } \\
\text { tahapan pencalonan }\end{array}$ & $\begin{array}{l}\text { - Melakukan konsolidasi } \\
\text { dan sosialisasi dengan } \\
\text { stakeholder pemilu yang } \\
\text { lain } \\
\text { - Hearing dengan DPRD dan } \\
\text { pemerintah daerah terkait } \\
\text { tahapan pencalonan }\end{array}$ \\
\hline Partai Politik & 6 & $\begin{array}{l}\text { - Membangun koalisi dengan } \\
\text { target semua partai politik } \\
\text { bergabung } \\
\text { - Melakukan mediasi dengan } \\
\text { DPP }\end{array}$ & $\begin{array}{l}\text { - Melakukan penjaringan di } \\
\text { tingkat DPC/D } \\
\text { - Melakukan branding politik } \\
\text { atas pasangan calon yang } \\
\text { telah disepakati koalisi }\end{array}$ \\
\hline Akademisi & 5 & $\begin{array}{l}\text { - Menilai ada upaya } \\
\text { memborong partai politik } \\
\text { - Menyebut mengurangi } \\
\text { kualitas demokrasi pilkada }\end{array}$ & $\begin{array}{l}\text { - Menganalisis bahwa } \\
\text { komunikasi yang dibangun } \\
\text { DPC dan DPP tidak selaras } \\
\text { dengan kepentingan daerah } \\
\text { - Merekomendasikan } \\
\text { kembali pada aturan lama } \\
\text { agar kepala daerah dipilih } \\
\text { oleh DPRD } \\
\text { - Berharap ada revisi atas } \\
\text { aturan calon tunggal dalam } \\
\text { pilkada. }\end{array}$ \\
\hline $\begin{array}{l}\text { Tokoh } \\
\text { Masyarakat }\end{array}$ & 7 & $\begin{array}{l}\text { - Prihatin dengan langkah } \\
\text { politik calon yang } \\
\text { melakukan borong semua } \\
\text { partai politik }\end{array}$ & $\begin{array}{cc}\text { - Tidak merasa nyaman } \\
\text { dengan konsolidasi calon } \\
\text { tunggal }\end{array}$ \\
\hline
\end{tabular}




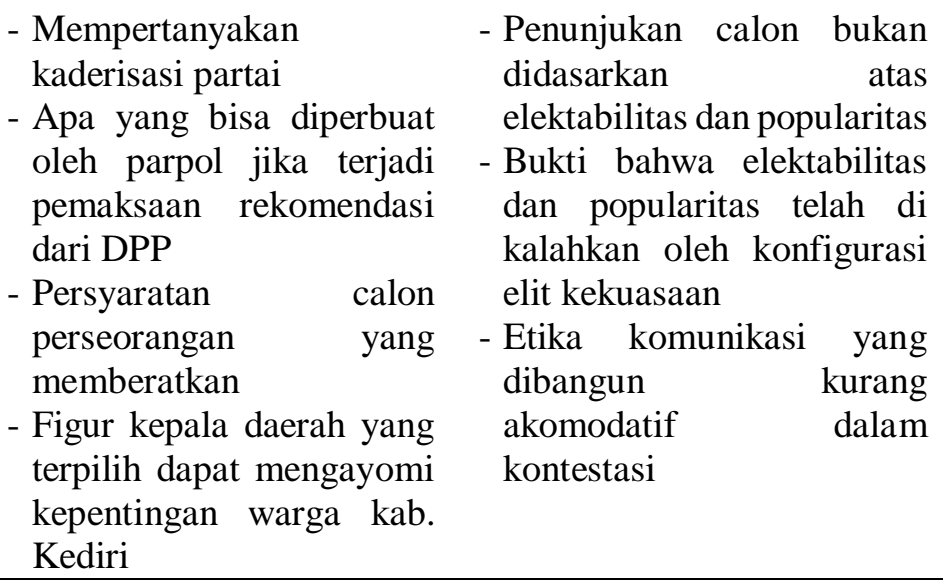

Dari tabel di atas, menunjukan bahwa penyelenggara telah berusaha melakukan tanggung jawabnya atas amanah konstitusi. Sedangkan partai politik di tingkat daerah tidak berdaya atas rekomendasi calon oleh DPP. Tidak ada perlawanan dari pengurus partai politik di daerah karena rekomendasi merupakan kewenangan pengurus DPP masing-masing partai politik.

Upaya maksimal dari kaum elit kekuasaan untuk menentukan pasangan calon bupati dan wakil bupati ini sebenarnya merupakan bukti telah terdapat upaya praktek konfigurasi politik. Konfigurasi politik yang dibangun adalah dengan membangun komunikasi dari atas ke bawah sehingga adanya calon tunggal ini merupakan proses komunikasi politik transaksional berdasarkan kepentingan elit kekuasaan.

Merujuk istilah hegemoni dari Gramsci dengan pendekatan dimensi kelas dan nasional kerakyatan. Adanya fenomena calon tunggal pada pilkada kabupaten Kediri ini menunjukan bahwa ada kelas-kelas tertentu yang menentukan kebijakan dan bukan muncul dari kehendak rakyat. Selain itu, konsekuensi dari fenomena calon tunggal ini setidaknya berimplikasi pada pandangan telah terjadi ketidaksesuaian akibat dari hegemoni moral para pemangku kebijakan dengan kenyamanan publik. Dalam prespektif hegemoni intelektual, juga memberikan gambaran tentang bagaimana konfigurasi komunikasi politik dilakukan dengan mendesain calon tunggal pada tingkat pusat bukan menyerap aspirasi dari bawah.

Strategi dalam komunikasi politik memang dimungkinkan untuk melakukan langkah-langkah strategik dengan menghitung realitas dilapangan maupun kekuatan politik yang dominan. Persepsi atas hadirnya calon tunggal pada pilkada kabupaten Kediri tentu akan dilihat bagaimana sosok pasangan Mas Dhito dan Mbak Dewi akan berkolaborasi. Klaim popularitas Mas Dhito hanya pada kekuatan sebagai putra pejabat tinggi di negeri ini akan terabaikan, jika pasangan ini mampu menunjukan kompetensi dasar sebagai pemimpin. Tawaran program yang rasional dan terukur juga dapat meyakinkan khalayak sehingga elektabilitas pasangan ini menjadi maksimal meski terdapat keraguan publik. 


\section{Simpulan}

Proses munculnya fenomena calon tunggal pada pilkada kabupaten Kediri diawali dengan adanya penjaringan partai politik di tingkat daerah. Rekomendasi diberikan kepada Mas Dhito dan Mbak Dewi oleh semua partai politik yang memiliki kursi di DPRD. Keputusan rekomendasi merupakan kewenangan Dewan Pimpinan Pusat (DPP) sehingga pengurus pada tingkat kabupaten maupun provinsi harus mengawal keputusan dari DPP. Meski terdapat beberapa regulasi yang mengatur tentang mekanisme pencalonan kepala daerah, pada prakteknya tidak mampu menghindari adanya calon tunggal yang dianggap dapat mengurangi nilainilai demokrasi dalam kontestasi pilkada.

Konfigurasi komunikasi politik dalam memunculkan calon tunggal di pilkada kabupaten Kediri ditandai dengan pendekatan elit kekuasaan. Komunikasi negoisasi diawali oleh petinggi-petinggi partai politik untuk mengkondisikan jaringan struktur partai tertinggi yakni DPP. Hal ini menunjukan tidak ada kewenangan pengurus partai politik ditingkat DPC untuk mendengar aspirasi masyarakat didaerah. Komunikasi politik yang dibangun utnuk mewujudkan calon tunggal pada pilkada kabupaten Kediri ini juga merupakan proses komunikasi politik transaksional sebagai bagian produk politik yang sah menurut aturan dalam rangka memperkuat kepercayaan publik.

\section{Ucapan Terima Kasih}

Artikel ini dibuat berdasarkan hasil penelitian mandiri yang dilakukan dengan melihat fenomena calon tunggal pilkada serentak tahun 2020. Penulis mengucapkan terima kasih kepada semua informan yang telah membantu memberikan data dalam penelitian ini. JTV Kediri dan Kediri Post atas kesempatan untuk memberi ruang dalam wawancara penelitian ini.

\section{Daftar Pustaka}

Aspinall, E., \& Berenschot, W. (2019). Democracy for Sale: Elections, Clientelism, and the State in Indonesia. Cornell University Press

Bawaslu, (2018). Fenomena Calon Tunggal Pilkada (Studi Kasus pada Pilkada 2018 di 16 Kabupaten/Kota. Diterbitkan BAWASLU, Jakarta.

Chaniago, P. S. (2016). Evaluasi Pilkada Pelaksanaan Pilkada Serentak Tahun 2015. Politik Indonesia: Indonesian Political Science Review. https://doi.org/10.15294/jpi.v1i2.6585

Fachrurozi, M. H. (2016). Revolusi Demokrasi: Suatu Gagasan Memperbaiki Demokrasi Indonesia. MOZAIK: Jurnal Ilmu-Ilmu Sosial Dan Humaniora. https://doi.org/10.21831/moz.v8i1.10768

Gazali, E. (2004). Interaksi Politik dan Media : Dari Komunikasi Politik ke Politik Komunikasi. Jurnal Ilmu Sosial Dan Ilmu Politik.

Gramsci-Roger Simon. (2012). Gagasan-gagasan politik Gramsci-Roger Simon. Pustaka Pelajar. 
Prilani, Setio Budi H. Hutomo: Konfigurasi Komunikasi Politik atas Fenomena Calon Tunggal Pada Pilkada Kabupaten Kediri Tahun 2020

Gunawan Gunawan; Bainus; A., \& Paskarina, C. (2020). Strategi politik koalisi partai dalam pemenangan paslon kepala daerah : studi kasus pada pilkada kabupaten nagan raya tahun 2017. POLITEA : Jurnal Politik Islam.

John, S. (2016). Budaya Populer dan Komunikasi Politik. Nusamedia.

Hanafi, R. I. (2014). Pemilihan Langsung Kepala Daerah di Indonesia: Beberapa Catatan Kritis Untuk Partai Politik. Jurnal Penelitian Politik.

Harahap, H. (2016). EVALUASI PELAKSANAAN PILKADA SERENTAK TAHUN 2015. Jurnal Renaissance.

Kaid, L. L. (2004). Handbook of political communication research. In L. Bathgate (Ed.), Handbook of Political Communication Research. Lawrence Erlbaum Associates Publishers. https://doi.org/10.4324/9781410610584

Lemhannas RI, Edisi 42 Juni 2020, http://www.lemhannas.go.id/images/Publikasi_Humas/Jurnal/Jurnal_Edisi _42_Juni_2020.pdf

Lubis, Djoharis (2020), Pilkada Serentak 2020 Di Tengah Gelombang Pandemi Covid-19: Apakah Menghasilkan Kepemimpinan Yang Efektif Berbasis Multikultur? J. 66, Jurnal Kajian

Mahkamah Konstitusi. (n.d.-a). Perubahan Putusan Mahkamah Konstitusi No. 2 tahun 2015 menjadi Perubahan Putusan Mahkamah Konstitusi No. 2 tahun 2017.

Mahkamah Konstitusi. (n.d.-b). Putusan Mahkamah Konstitusi No. 100/PUUXII/2015.

Md, M. M. (1999). Hukum dan Pilar-Pilar Demokrasi. In Gama Media.

Nasional.kompas.com/read/2020. (n.d.). Retrieved October 13, 2020, from https://nasional.kompas.com/read/2020/09/14/14274881/ini-daftar-25daerah-dengan-bakal-paslon-tunggal-di-pilkada-2020?page $=$ all

Negara, S. D. (2020). Book Reviews democracy for sale: Elections, Clientlism and the state in Indonesia. By Edward Aspinall and Ward Berenschot. Ithaca, New York: Cornell University Press, 2019). Softcover: 308pp. Contemporary Southeast Asia. https://doi.org/10.1355/cs41-3e

Nugraha, R. P., \& Puspitasari, A. C. (2018). Strategi Kampanye Gubernur Basuki Tjahaja Purnama-Djarot Saiful Hidayat Dalam Menghadapi Pilkada Dki Jakarta 2017. Jurnal Komunikasi. https://doi.org/10.24912/jk.v10i2.206

Perloff, R. M. (2017). The Dynamics of Political Communication. In The Dynamics of Political Communication. https://doi.org/10.4324/9781315624426

Prayudi, Made Aristia (2013). Posisi birokrasi dalam persaingan politik pemilukada. P3DI Setjen DPR Republik Indonesia dan Azza Grafika.

Rani, Samsul, 2018, Dinamika Komunikasi Politik Dalam Pilkada Di Indonesia, Jurnal Alhadharah Vol. 17 No. 33 Januari - Juni 2018 h.125-126 http://jurnal.uin-antasari.ac.id/index.php/alhadharah/article/view/2376

Romli, L. (2018). Pilkada Langsung, Calon Tunggal, dan Masa Depan Demokrasi Lokal. Jurnal Penelitian Politik. https://doi.org/10.14203/jpp.v15i2.757

Sarjan, S., AL Kindi Mulya, K., \& Chadijah, S. (2020). PROBLEMATIKA DAN TEKNIS PENYELENGARAAN PEMILIHAN KEPALA DAERAH PADA MASA PANDEMI COVID 19. Rechtsregel: Jurnal Ilmu Hukum. https://doi.org/10.32493/rjih.v3i1.6620 
Susanto, E. H. (2013). Dinamika Komunikasi Politik dalam Pemilihan Umum. Jurnal Kajian Komunikasi. https://doi.org/10.24198/jkk.v1i2.6041

Yin, R. K. (2009). Case Study Research Design and Methods Fourth Edition. In Applied Social Research Methods Seiries. 